\title{
Institutional Drift of the Healthcare System in Poland - the Institutional Approach
}

\author{
Jarosław Plichta
}

Cracow University of Economics, Poland

\begin{abstract}
The healthcare system in Poland has undergone a series of changes for many decades. For many years the entire system has been in a state of drift. The government has searched for a solution to this situation and a way out of the "path dependence". Regardless of political aspects, centralisation has numerous disadvantages from the institutional point of view. In spite of the neo-classical approach in healthcare economics prevails in the literature, some scholars and practitioners propose alternative approaches, including institutional economics and its successor, New Institutional Economics. The approach emphasises the institutional environment of healthcare and take consideration of many different stakeholders, including informal institutions, thereby provides a broader view of the national healthcare system. The article attempts to examine the main challenges to the healthcare system in Poland from an institutional point of view. Suggestions are offered for how policy makers and industry players may initiate institutional change in healthcare.
\end{abstract}

Paper Type: Conceptual Paper

Keywords: Health Economics, New Institutional Economics, Agency Problem, Transaction Costs, Health policy 


\section{Introduction}

Healthcare is inherently different from other types of services. National healthcare system is complex and varies from countries to countries, even among countries sharing similar institutional characteristics. An overview of healthcare systems across the globe indicates that there is no model solution applicable in all conditions. Therefore, every country tries to work out its own concept and healthcare system embedded in a specific institutional environment (Jan, 2000). As the characteristics of these systems show, the application of the institutional approach in the healthcare sector seems by all means justified. It combines the output of economics, management, sociology and psychology, and considers the complex character of social phenomena in a holistic way (Furubotn and Richter, 2005). However, the neo-classical approach is still a prevailing approach in contemporary healthcare economics (Hodgson, 2008; Langer et al., 2009). Neo-classical approach coincides with the notion of rational choice theory which suggests that people act rationally in making economic decisions (Hodgson, 2008). The neo-classical approach to health economics can be seen in governmental attempts in delivering cost-effective healthcare for those in need.

Over the past few decades, the healthcare system in Poland undergoes a series of radical changes after the fall of communism. In 1999, the government launched a major reform of the healthcare system. While government intervention for health reform is a prerequisite, it is important to recognise that the understanding of institutional environment go far beyond governmental command and control. As Cassels (1995, p. 4) put it: "Reform is likely to depend more on strengthening the hand of groups outside government (such as NGOs, research institutions, user groups, community organisations and private sector providers) who can influence the environment in which the civil service operates". An analysis of the institutional environment can provide a broader picture of the health reform. Such institutional analysis is commonly used in developed countries (Ruef and Scott, 1998), but it is often overlooked in transition economy. In reference to healthcare economics literature, however, we can find a number of qualities characterising the healthcare sector, which are typical of the New Institutional Economy:

- the need for healthcare is a derivative of demand for good health;

- externalities arise from communicable diseases and immunisation (Boulhol et al., 2012, p. 7);

- $\quad$ supplier-induced demand (Hodgson, 2008);

- there is an asymmetry of information between patients and doctors (Ludwig et al., 2010);

- physicians and patients may be equally uncertain about the disease (Han et al., 2011).

Based on the notion of rationality and agency theory, the New Institutional Economics provide a unique framework to analyse the design of interfaces within and among organisations. When the first study of modern healthcare economics came out in the 1970s, Arrow (1963) underlined the occurrence of serious problems with asymmetry

International Journal of Management and Applied Research, 2017, Vol. 4, No. 3 
of information and behavioural uncertainty in healthcare. In relation to that, growing attention has been paid to the phenomenon of demand induced by physicians in healthcare (Boulhol et al., 2012; Han et al., 2011; Hodgson, 2008). The physiciansinduced demand indicates that the readiness to pay for healthcare services usually depends on professional advice and diagnosis from service providers (Han et al., 2011). Such a system, promoting the quality of services, may function in market or quasi market solutions, providing the insured with an opportunity to choose the place of treatment, arranging for financing by state institutions and supplying it through competing private insurance companies.

This article attempts to examine the present healthcare system in Poland from an institutional perspective as well as indicate the main directions of actions. Due to the limits on the size of the article, it focuses only on the most important aspects, referring to selected streams of New Institutional Economics (NIE), providing an opportunity to search for solutions in the healthcare sector not only in Poland.

\section{Diagnosing of the problems of health service in Poland on the institutional level}

The Polish healthcare system cannot free itself of the historical baggage of institutional 'path dependence' or organisational, social, cultural and mental habits and negative political influences ("Understanding Institutional and Organizational Path Dependencies", 2010). Despite several attempts undertaken to change the inherited post-socialist system none of them has managed to produce any effects in the form of better diagnostics, more effective treatment or rational fund management in public healthcare institutions. Both in the general economic system and in the healthcare sphere, the phenomenon of institutional drift has been observed for a few years (Hausner et al., 2012; Pysz et al., 2014; Redmond, 2005). Constant announcements of reforms and modifications in the sphere of formal institutions, such as laws aiming at the improvement of the system, remain the only response to this.

Attempts to reform the healthcare system in Poland were unsuccessful which could be explained by varying (sometimes conflicting) political agendas of the parties in power as well as by lack of institutional capacity to design and implement effective system (Sagan et al., 2011). The restructuring path which began in 1999 and consisted in creating the foundations for a healthcare fund system, was abandoned a few years later and followed by the establishment of a single centralised institution of the National Health Fund (Polish: Narodowy Fundusz Zdrowia - NFZ) with its regional branches (Golinowska et al., 2012; Kuszewski and Gericke, 2005; Sagan et al., 2011). Starting from 2018, healthcare in Poland will be provided by the National Health Service and the NFZ will be abolished (Radziwiłl, 2016). The healthcare services will be financed from the state budget and it will include all patients, including those who are not insured under the present system and thus have no access to healthcare. Under the current healthcare system, some Polish citizens and foreign workers who have shortterm contracts with no health benefits do not receive health coverage. The health reform envisions to provide universal health coverage to all citizens (Radziwiłł, 2016). Statistics show that public expenditure on health in Poland constitutes about $6.6 \%$ of

International Journal of Management and Applied Research, 2017, Vol. 4, No. 3 
GDP, which is comparatively lower than the average of $7.6 \%$ for European Region (Sagan et al., 2011). Arguably however, the amount of health spending does not always translate to adequate improvement in citizens' health and the quality of service.

To date, problems such as ineffective allocation of funds (Sagan et al., 2011), health literacy problem (Tobiasz-Adamczyk et al., 2009), inequalities in access to care (Boulhol et al., 2012; Tobiasz-Adamczyk et al., 2009) and unsatisfactory healthcare quality (Sagan et al., 2011) still persist in Polish healthcare system. In 2014, $12.9 \%$ of the population aged 16 and over in Poland reported that they had unmet needs for medical examinations or treatment, significantly above the average of $6.7 \%$ in all EU countries (Eurostat, 2016). According to the Centre for Public Opinion Research (Polish: Centrum Badania Opinii Społecznej, CBOS), an opinion polling institute, majority of patients (over $73 \%$ ) positively asses the availability and the quality of services provided by general practitioners (Centrum Badania Opinii Społecznej, 2012). However, an equally large group of respondents assesses the access to diagnostic and specialist services as poor. In the majority of opinions expressed by healthcare sector representatives and experts, the main reason for such a state of affairs is too low percapita spending on healthcare in Poland (CBOS, 2012).

The responsibility for the functioning of healthcare in Poland has been distributed over a number of entities: municipalities, poviats, voivodeships, the National Health Fund (NFZ) and the Ministry of Health. To a certain extent, the responsibilities of NFZ overlap and the supervisory power of the ministry is poorly defined (Sagan et al., 2011). The NFZ has been subject to criticism due to its monopolistic position in health insurance (Sagan et al., 2011) as well as its inefficiency in management and resource allocation (Nieszporska, 2017).

There are two approaches to fund healthcare: first, the public source of financing which comes from the state budget and tax revenues; and second, the private source of financing (Pagan, et al., 2011; Sekhri and Savedoff, 2004). Out-of-pocket payment on healthcare service is a common form of health financing in developing countries due to the limited ability to generate tax revenue and spend on healthcare (Sekhri and Savedoff, 2004). Majority of developed countries adopt a mixed approach, which seems to be the best reflection of the institutional conditioning of human activity and the functioning of social and economic processes. The term "mixed" does not mean a simple combination of public and free market solutions, but their application to build an institutional matrix based on historical, economic, and social conditions (Kirdina, 2003). An analysis of the mechanisms of their operation and common elements allows avoiding mistakes in design and implementation on the strategic and operational levels.

Until 1999 the system of financing healthcare in Poland followed the Soviet solution, so-called Semashko model. It consisted of a healthcare system funded entirely by the state through taxation. The Communist regime had a long-lasting impact on the Poles' attitudes towards universal healthcare system where government takes full responsibility in healthcare (Sagan et al., 2011: p. 17). What arises from the social profile of the Poles is that in comparison with other nations in Europe, they are more

International Journal of Management and Applied Research, 2017, Vol. 4, No. 3 
individualistic than collective. Therefore, it is difficult to say today which system would be favoured by the citizens.

At present, the system which functions in Poland is a centralised operation based on National Health Fund (NFZ) redistribution of funds raised from contributions (which in fact perform the role of a tax) provided by entities offering medical services on the basis of contracts negotiated each year. A small portion of financing comes from private funds allocated officially to public and non-public healthcare entities, including doctor's surgeries, and funds changing hands on the grey market to bypass the official system of revenue registration (Nojszewska, 2011). The shortages of funds in the healthcare system are replenished by the state budget (Plichta, 2016). This applies not only to paying contributors but also to professional and social groups, such as farmers or uniformed services, who take full advantage of healthcare while being exempted from paying contributions. With the ageing of society, the number of people requiring rising expenses on treatment, rehabilitation and palliative care will be rising.

Most healthcare entities are owned by the State Treasury (so-called public healthcare facilities, Polish: publiczne zakłady opieki zdrowotnej - ZOZ), local governments (poviats, cities, municipalities) or the so-called non-public healthcare facilities (Polish: niepubliczne zakłady opieki zdrowotnej). The entities transformed after 1998 into nonpublic healthcare facilities (Polish: niepubliczne zakłady opieki zdrowotnej - NZOZ) are dominated by limited liability companies (Polish: spółki z.o.o.), in which local governments are usually the majority or exclusive stockholder. After decades of changes in healthcare sector, it has now become possible to transform independent public healthcare organisations into private ones and create new entities within this legal status (Nieszporska, 2017).

The whole process of service provision and redistribution of funds forms a complex system of contracts and relationships which indicates a typical agency problem (Eisenhardt, 1989). Agency problem occurs when there is a conflict of interest between the needs of principal and agent (Langer et al., 2009). Using the metaphor of a contract, agency theory describes the relationship between agents and their principals and delegation of control where the agent acts on behalf of their principal (Arrow, 1963; Eisenhardt, 1989; Langer et al., 2009). The principal-agent problem in healthcare asserts that insurance and healthcare providers will act to optimise their profits at the expense of the patients' interests (Langer et al., 2009). Issues such as information asymmetry (Arrow, 1963; Eisenhardt, 1989; Ludwig et al., 2010) and effort-aversion (Eisenhardt, 1989) may affect the quality of services provided by the agents. Here, the self-interest of the agents has overshadowed the interest of the principal since the agents do not behave as agreed.

However, the principal agent relationship in healthcare sector is rather complicated since the agents and principals have different objectives and division of labour (Ludwig et al., 2010). First, there is a principal agent relationship between patients (principals) and physicians (agents), where the healthcare professionals determine and act on patients' best interest. Second, there is another principal agent relationship inside the hospital, where the hospital administration (the principal) hires physicians (agents) to treat patients. Third, outside the hospital, there is a principal agent

International Journal of Management and Applied Research, 2017, Vol. 4, No. 3 
relationship between health insurance providers (agents) and policy buyers (principal). It is not uncommon for physicians to find themselves in a situation where they must serve two or more principals with conflicting objectives (Langer et al., 2009). The notion of 'double agent' (Langer et al., 2009) illustrates the dual obligations of the physicians both to patients and employers (hospitals, clinics, or healthcare insurance organisations). Budget constraint calls for the need of greater efficiency and better resources allocation, but in the case of Polish healthcare system, it only shifts the responsibility to the physicians (Czarzasty, 2006).

Over the years, the healthcare system in Poland has faced problems with fiscal resources and restructuring (Sagan et al., 2011). Health reforms in Poland have been aimed at increasing rationality in service delivery (Kuszewski and Gericke, 2005). Arguably, the rational-choice model fails to consider the complexity of healthcare system wherein patients, physicians, and policy makers pursue competing objectives. Drawing from agency theory and rational choice model, an institutional approach to healthcare suggests that institutions enable and constraint organisations and individuals in accomplishing their goals (Ruef and Scott, 1998). Because institutional theory focuses on institutional environment and role of institutions in society, it can be used to describe the process of health reform and the influences of social actors to healthcare services. There are growing empirical studies use institutional approach in examining healthcare organisations. One notable study was conducted by Ruef and Scott (1998) which shed some light on hospital survival using institutional approach.

Taking the institutional perspective into consideration, the Polish healthcare system has a number of challenges, including:

a) Stringent budget constraint. Limited budgetary funds induce lobbying mechanisms and manual control of expenses, thereby decreasing incomes of hospitals and yet at the same time contributing to hospital's growing debts (Boulhol et al., 2012; Kuszewski and Gericke, 2005). Until 1999, the healthcare services were regulated and funded by the central government (Czarzasty, 2006; Kuszewski and Gericke, 2005). On 1 January 1999, the National Healthcare Insurance Act was introduced by the Polish government. This Act envisaged a shift from a centralised budget-based system to a decentralised insurance-based system, which operates under a special fund with nation-wide coverage (Czarzasty, 2006). After the health reform in 1999, the institutional debts had to be cleared so that the medical providers can restart with clear accounts. However, this did not stop the accumulation of further debts (Boulhol et al., 2012). Since the state could not finance health reforms and the population could not afford adequate insurance contribution, the restructuring of healthcare in Poland stalled (Kuszewski and Gericke, 2005). The changing rates of health insurance contributions (Czarzasty, 2006), poor management (The World Bank, 2014), and the tendency to reimburse medical providers for over-production or excess service provision (Boulhol et al., 2012) all add up to hospital debts in Poland. Nonetheless, the financial sustainability of Polish healthcare system has improved over time and some of the hospitals have made good progress at resolving debts (The World Bank, 2014).

International Journal of Management and Applied Research, 2017, Vol. 4, No. 3 
b) Shortage of healthcare practitioners. One way of limiting health spending is to restrain the volume and price of labour inputs (Boulhol et al., 2012), which subsequently making the medical profession less attractive. For years, limited financial resources led to unsatisfactory contract rates between the National Health Fund (Narodowy Fundusz Zdrowia, NFZ) and the healthcare providers. In general, physicians argued that the contract terms offered by the NFZ were unsatisfactory, as they extended the duties for physicians without increasing their payments (Czarzasty, 2006). At the end of 2003, Poland witnessed a period of mass protest of in healthcare sector, operating under the so-called "Zielenogórskie agreement" (Kuszewski and Gericke, 2005). There have been repeated attempts at resolving salary issues, and yet the career prospects of medical profession remain unattractive for the younger generations (Boulhol et al., 2012) and job dissatisfaction has given rise to the "brain-drain" of medical professionals to other countries (Boulhol et al., 2012; Kuszewski and Gericke 2005; Sagan et al., 2011).

c) Thin private insurance market. In Poland, patients are covered by mandatory health insurance which forms the major source of healthcare financing (Kuszewski and Gericke, 2005). The country has some pre-paid schemes which cover people active in labour markets, alienating those who are in long-term sickness or reached pension age (Boulhol et al., 2012). One way to complement public insurance schemes is to extend insurance coverage through the development of private health insurance (Sekhri and Savedoff, 2004). However, the development of private health insurance has faced a number of challenges, including: first, lack of a basket of clearly defined guaranteed medical services (Boulhol et al., 2012), and second, lack of transparent healthcare services (Kuszewski and Gericke, 2005).

d) Limited use of performance indicators. Following the health reform, a series of changes have been made in Polish healthcare system. Performance management in healthcare, however, appears largely unpopular in Poland. Managers in Polish hospitals monitor financial data, without combining these data to measure performance (The World Bank, 2014) as well as linking performance to remuneration (Boulhol et al., 2012; Kuszewski and Gericke, 2005). Performance indicators serve as a benchmark for organisations to learn and improve (Porter, 2010; Smith, 2002).

e) Lack of healthcare transparency. The lack of transparency around the cost and quality of healthcare services put patients at a disadvantage. Poor waiting list management, lack of guaranteed medical services, or limited provision of healthcare services all contribute to the lack of healthcare transparency (Kuszewski and Gericke, 2005, p. 34). Incomplete or distorted information can cause patients to distrust their doctors. Information asymmetry (Ludwig et al., 2010) or health literacy problem more specifically (Langer et al. 2009) is a persistent issue in healthcare sector, where the physicians have information advantage over their patients.

f) The fragmentation of contracts. The healthcare service delivery system is also at risk of becoming fragmented since organisational units such as hospitals or clinics became increasingly autonomous. Periodically, NFZ gives grants for healthcare 
providers and healthcare providers who offered the most favourable terms conclude a contract with the NFZ (Kuszewski and Gericke, 2005). The practice of contracting out healthcare services appears to result in fragmentation, which has negative consequences in terms of efficiency and accountability (The World Bank, 2014). Having a mix of healthcare providers could be cost-ineffective due to duplication of services, poor coordination between different providers, and inefficient resource allocation.

g) Poor access to new technologies. According to Boulhol et al. (2012: 15), diagnostic equipments such as magnetic reasoning imaging (MRI) is only about a third of the average OECD country level. Moreover, the launch of an electronic health information system has been significantly delayed in Poland (Adamski, 2014; Supreme Audit Office, 2013). An obligatory transition from a voluntary system of Electronic Health Records was ordained by the Act of 28 April 2010 on the System of Information in Healthcare (Adamski, 2014). The system was supposed to allow immediate for healthcare practitioners to access health records at timely manner; however, the IT systems of healthcare providers are insufficiently developed to allow for the transition. More specifically, some healthcare providers set up independent, local information systems which are not mutually compatible (Boulhol et al., 2012), thereby precluding the interoperability of a centralised healthcare information system (Adamski, 2014).

h) Long waiting time. Long waiting time is often cited as the most frequent reason for unmet medical need in Poland (Eurostat, 2016). While accessibility to primary care is quite good in general, accessibility to specialist care is unsatisfactory due to long waiting times (Boulhol et al., 2012). In 2013, a 'waiting lists package' was introduced by the Ministry of Health, aiming to decrease waiting time; however, patients face longer times after the implementation of waiting lists package (Zabdyr-Jamróz, 2015). Some patients seek medical assistance in emergency rooms even when they are not that sick so that they can avoid queues to specialists. Over the years, the Poles have developed many different strategies to obtain faster and more personalised medical services (Boulhol et al., 2012), which are often borne directly from patients. These recent trends not only disturb the functions of individual healthcare entities, but also increase the operating costs without actually improving the quality of care.

i) Low health literacy. There has been a lack of interest in health promotion by the Polish government due to insufficient financial resources as well as organisational supports (Tobiasz-Adamczyk et al., 2009). According to CBOS survey, up to 37\% (2012) and 31\% (2016) of Poles believe that taking care of their own health is not important (Boguszewski, 2016, p. 8). Ironically, the Poles have the tendency to over-consume drugs through self-medication (Boulhol et al., 2012, p. 20). Following a period of social-political transformation, there has been a health promotion organised by independent associations targeted mostly groups of higher socioeconomic status which deepen existing health inequalities (TobiaszAdamczyk et al., 2009).

International Journal of Management and Applied Research, 2017, Vol. 4, No. 3 


\section{The structure of main transaction processes of the healthcare system in Poland}

In every country the institutional system is made up both of entities performing specific functions in the processes of production and exchange, as well as formal and informal standards and rules regulating their activities. The healthcare system is a subsystem of relations and transactions taking place at many different levels. One can indicate a few key relations in it, creating a general structure of the healthcare system in Poland:

1) Relations between citizens and public institutions responsible for the functioning of the healthcare system (e.g. geopolitical entity, government, parliament, local city councils);

2) Relations between patients and healthcare institutions (public and private ones);

3) Relations between state institutions and local government institutions and healthcare entities;

4) Relations between citizens themselves in the process of building social ties.

Some theories from new institutional economics call into question the viability of transactional-based contracting. At individual level, the role of patients or citizens within the institutional setting can be analysed with the agency theory. A citizen, as a principal, forms relation with agents, namely public institutions and healthcare organisations in receiving care and treatment. Despite public institutions such as NFZ and Ministry of Health are not providing healthcare directly to the citizens, these institutions play a regulatory role in planning and allocating resources (Plichta, 2016; Sagan et al., 2011). In the agency theory, such implicit contractual relationship (Langer et al., 2009) is based on trust, which tends towards the relational rather than transactional (Palmer, 2000). The institutional capacity and environment to support the operation of contracts must also be taken into consideration in understanding the relational contracts between the citizen and institutions (Palmer, 2000; Ruef and Scott, 1998).

At the time of writing, the institutions responsible for healthcare in Poland are as follows: the Ministry of Health, NFZ and local government units, mainly poviats. NFZ is responsible for financing healthcare services and contracting healthcare services to hospitals; the NFZ cannot be involved in the provision of health care services due to the strict separation between healthcare provision and public financing (Boulhol et al., 2012). Non-contracted hospitals would be deprived of financing (Sagan et al., 2011). Because of limited financial resources, hospitals try to limit admission rate and primary care doctors rarely issue referrals (Nieszporska, 2017). Boulhol et al. (2012) suggest that the separation of responsibilities and poor coordination between the NFZ and healthcare providers have lead to permanent debt and loss among public healthcare institutions. As NFZ has no mandate to invest in medical facilities and local governments lack the resources to do so, hospitals continually fall into debt in purchasing equipments and updating their wards (Golinowska et al., 2012). In short, the current public financing and healthcare provision are performed in an inefficient way.

International Journal of Management and Applied Research, 2017, Vol. 4, No. 3 
On the other hand, the informal institutions in Poland appear to have little influence over the healthcare system. In spite of the fact that a great number of social organisations promoting healthy lifestyle have been founded in recent years, their range of activities is somewhat limited and the issues of inequality to access care still persist (Tobiasz-Adamczyk et al., 2009). Reducing inequalities and broaden access to healthcare have been main priorities for the Poles (Boulhol et al., 2012). However, the problem is that, some citizens take advantage of the financial assistance (Sagan et al., 2011), thereby raising the issue of free riders (Paolucci, 2011, pp. 25-26).

Instead of incurring individual expenses on preventive medicine, free riders will choose free of charge services in the healthcare system as a cheaper alternative. This leads to adverse selection, with people who need care more entering the healthcare system, motivating those for whom health is significant because it leads to higher earnings as well as serves other needs. Thus, it has a measurable monetary value and plays an important role in the comparative analysis of life decisions. This pseudoequality mechanism and redistribution of income in society, based exclusively on the taxation of labour, imposes an additional penalty on working people and their incomes, which, accompanied by the growing operating costs of the system, will result in more and more serious economic and social conflict. Free riders will be more and more inclined to treat effects and not causes of illnesses, which is much more expensive.

It should be emphasised that the solidarity system set out in the Polish constitution applies only to the share in the community of risk and the obligation to pay contributions, and not in the guarantee of healthcare on a proportionally high level (Lach, 2011). Folland et al. (2010) state that human health is a derivative of three groups of factors: first, genetic predisposition; second, individual behaviour (e.g. diet, lifestyle); and finally, environmental conditions, including the natural, technical, economic environment. Depending on the place of residence, individual groups of factors may remain in various proportions with one another. To a great extent, an individual's health depends on his or her conscious choices and actions at both individual and societal levels. Therefore, the basis for the effectively functioning healthcare system should be an insurance system which would combine an individual's health with the condition of other members of society whose health primarily arises from reasons independent of them, e.g. from ecological policy or genetic predisposition (Paolucci, 2011, p. 93). An example of such a combination of social and environmental factors is a problem of smog in many places in Poland. On the one hand, it is caused by a traditional, coal-based system of residential heating and, on the other, by deliberate burning of waste materials in furnaces, which causes pollution with heavy and toxic compounds alike.

\section{Suggestions for institutional changes}

Economist Arthur Cecil Pigou's case for government intervention is well cited in literature. To rectify the shortcoming of free market in dealing with negative externalities, Mr. Pigou advocated "government intervention" in the form of taxation, subsidy, and regulation. In the case of Polish healthcare system, however, taxation and

International Journal of Management and Applied Research, 2017, Vol. 4, No. 3 
regulation will hardly change the current situation if institutional environment is not reformed accordingly. As Cassels (1995, p. 5) states: "The pressure to make rapid progress in reconstruction and rehabilitation may result in the recreation of the same of inequitable or inefficient systems that existed prior to the period of instability".

The source of financing healthcare could come from many different areas other than taxation. The system based on contributions which perform the role of quasi taxes encumbering the remuneration budget makes the state and its institutions the administrator (agent) of the citizens' money. It is a tax on salaries and in addition it is paid only by some working people (e.g. farmers or uniformed services do not pay). Its level is related to the total tax and pension burdens of remunerations. Although administrative costs connected with their service are about 3\% (NFZ + ZUS - Social Insurance Company), their ineffective allocation is a more serious problem.

On the basis of the presented assumptions and diagnoses of the condition of healthcare in Poland, we can mention a few main directions of necessary institutional changes, namely:

- creating an institutional matrix in the healthcare system, based on the analysis of contracts in the whole process of exchange and service provision, considering not only direct costs but also transaction costs ex-ante and ex-post;

- broadening the offer of private insurance and introducing the mechanisms of contracting services by private insurance companies, which will enforce participation in the basket of services now provided by public entities and including expensive treatments;

- ordering the ownership structure and creating new corporate governance based on the responsibility for the process, effects in healthcare, employing personnel and improving patients' health in connection with the register of services and applied drugs. In many countries investment in such systems resulted in tightening the system and considerable savings;

- ordering the medical education system at the level of university studies and providing access to specialisation to a bigger number of people;

- introducing medical service managers who will be remunerated not only for the effectiveness of entities, but also the effects of treatment in the long term;

- separation of insurance contribution from taxes, and gradually making it dependent on a patient's health;

- including schools, media and non-profit organisations in educational activity in order to change social awareness in respect of a conscious approach to the problems of healthcare;

- introducing the system promoting people who improve their health.

As Cassels (1995, p. 3) observed, health reform is concerned with defining priorities, refining policies, and reforming institutional environment. The pluralistic healthcare system of Poland will need to take into account institutional, technical and political

International Journal of Management and Applied Research, 2017, Vol. 4, No. 3 
factors (The World Bank, 2014). The pathway to create a transparent system should involve the wide range of stakeholders which would be affected by the reform.

\section{Conclusions}

The healthcare system in Poland, in spite of numerous attempts to change and improve it, is marked by institutional drift. It is characterised by strong attachment to historical background and a lack of comprehensive and pro-effective institutional. It focuses treating effects and not the root causes, while its activities frequently boil down to shifting obligations and funds within the existing system. The existing budget constraint should stimulate the rationalisation of expenses and give an impulse for change. The complicated system of ownership within the healthcare system blurs responsibility, which combined with a tendency to keep inefficient hospital wards open and a very flow influx of specialists contributes to that system's inefficiency. A detailed institutional analysis and verification of contract processes could detect systemic errors and serve as a basis for proposing changes aimed to meet its social and economic goals. This article shows a number of elements influencing the healthcare system in Poland. They are only an illustration of the method of approaching the analysis of the processes from the institutional point of view and might be used as a starting point for more universal approaches to solving economic and social problems.

\section{References}

1. Adamski, D. (2014), Overview of the national laws on electronic health records in the EU Member States: National Report for Poland, Belgium: Milieu Ltd.

2. Arrow, K.J. (1963), "Uncentrainty nad the Welfare Economics of Medical Care", Uncertainty in Economics, pp. 345-375. http://www.jstor.org/stable/1812044

3. Boguszewski, R. (2016), Zdrowie I Prozdrowotne Zachowania Polaków, No. 138/2016, CBOS, Warszawa, pp. 1-15.

4. Boulhol, H.; Sowa, A.; Golinowska, S, and Sicari, P. (2012), "Improving the Health-Care System in Poland", OECD Economics Department Working Papers, No. 957, Paris: OECD Publishing. https://doi.org/10.1787/5k9b7bn5qzvd-en

5. Cassels, A. (1995), Health sector reform: key issues in less developed countries, Geneva : World Health Organization

6. Centrum Badania Opinii Społecznej (CBOS) (2012), "Polacy o swoim zdrowiu oraz prozdrowotnych zachowaniach i aktywnościach”, CBOS, available at: http://www.cbos.pl/SPISKOM.POL/2012/K_110_12.PDF (accessed 19 June 2017)..

7. Czarzasty, J. (2006), "Doctors clash with the National Health Fund over healthcare agreement", EuroFund, available at:

https://www.eurofound.europa.eu/observatories/eurwork/articles/doctors-clashwith-the-national-health-fund-over-healthcare-agreement (accessed 19 June 2017).

International Journal of Management and Applied Research, 2017, Vol. 4, No. 3 
8. Eisenhardt, K. M. (1989), "Agency Theory: An Assessment and Review", Academy of Management Review, Vol. 14, No. 1, pp. 57-74. https://doi.org/10.5465/AMR.1989.4279003

9. Eurostat (2016), Unmet healthcare needs statistics, available at: http://ec.europa.eu/eurostat/statistics-

explained/index.php/Unmet_health_care_needs_statistics (accessed 19 June 2017).

10. Folland, S., Goodman, A.C. and Stano, M. (2010), The Economics of Health and Healthcare, 6th ed., Prentice Hall, Boston.

11. Furubotn, E. and Richter, R. (2005), Institutions and Economic Theory, University of Michigan Library, available at: https://doi.org/10.3998/mpub.6715.

12. Golinowska, S., Sicari, P., Sowa, A. and Boulhol, H. (2012), Improving the HealthCare System in Poland, OECD Economics Department Working Papers No. 957, https://doi.org/10.1787/5k9b7bn5qzvd-en.

13. Han, P.; Klein, W. and Arora, N. K. (2011), "Varieties of Uncertainty in Health Care", Medical Decision Making, Vol. 31, No. 6, pp. 828 - 838.

https://doi.org/10.1177/0272989X11393976

14. Hausner, J., Geodecki, T., Grzelak, G., Górniak, J., Mazaur, S., Szlachta, J. and Zaleski, J. (2012), Kurs Na Innowacje. Jak Wyprowadzić Polskę Z Rozwojowego Dryfu?, edited by Hausner, J., Fundacja Gospodarki i Administracji Publicznej, Kraków.

15. Hodgson, G.M. (2008), “An Institutional and Evolutionary Perspective on Health Economics”, Cambridge Journal of Economics, Vol. 32 No. 2, pp. 235-256. https://doi.org/10.1093/cje/bem033

16. Jan, S. (2000), "Institutional considerations in priority setting: transactions cost perspective on PBMA", Health Economics, Vol. 9 No. 7, pp. 631-641. https://doi.org/10.1002/1099-1050(200010)9:7<631::AID-HEC531>3.0.CO;2-N

17. Kirdina, S. (2003), "Institutional matrices and institutional changes", available at: https://mpra.ub.uni-muenchen.de/29691/ (accessed 20 November 2016).

18. Kuszewski, K. and Gericke, C. (2005), Health system in Transition: Poland, Copenhagen: European Observatory on Health Systems and Policies.

19. Lach, D.E. (2011), Zasada Równego Dostępu Do Świadczeń Opieki Zdrowotnej, Wolters Kluwer, Warszawa.

20. Langer, A., Schröder-Bäck, P., \& Brink, A. O. (2009), "The Agency Problem and Medical Acting: An Example of Applying Economic Theory to Medical Ethics", Medicine, Health Care And Philosophy: A European Journal, Vol. 12, No. 1, pp. 99-108. https://doi.org/10.1007/s11019-008-9138-y

21. Ludwig, M.; Van Merode, F. and Groot, W. (2010), "Principal agent relationships and the efficiency of hospitals", European Journal of Health Economics, Vol. 11, No. 3, pp. 291-304. https://doi.org/10.1007/s10198-009-0176-Z

22. Nieszporska, S. (2017), "Priorities in the Polish health care system", European Journal of Health Economics, Vol. 18, No. 1, pp. 1-5. https://doi.org/10.1007/s10198-016-0831-0

International Journal of Management and Applied Research, 2017, Vol. 4, No. 3 
23. Nojszewska, E. (2011), System ochrony zdrowia w Polsce, Wolters Kluwer.

24. Palmer, N. (2000), "The use of private-sector contracts for primary health care: theory, evidence and lessons for low-income and middle-income countries", Bulletin World Health Organisation, Vol.78, No.6, pp. 821-829.

25. Paolucci, F. (2011), Healthcare Financing and Insurance, Vol. 10, Springer Berlin Heidelberg, Berlin, Heidelberg, available at: https://doi.org/10.1007/978-3-64210794-8.

26. Plichta, J. (2016), "Institutional Conditions for Improving the Efficiency of the Healthcare System in Poland", in Dudycz, T., Osbert-Pociecha, G. and Brycz, B. (Eds.), The Essence and Measurement of Organizational Efficiency, Springer International Publishing, Cham, pp. 249-261. https://doi.org/10.1007/978-3-31921139-8_15

27. Porter, M.E. (2010), "What Is Value in Healthcare?", New England Journal of Medicine, Vol. 363 No. 26, pp. 2477-2481. https://doi.org/10.1056/NEJMp1011024

28. Pysz, P., Grabska, A. and Moszyński, M. (Eds.). (2014), Spontaniczne I Stanowione Elementy Ładu Gospodarczego W Procesie Transformacji. Dryf Ładu Czy Jego Doskonalenie?, Polskie Towarzystwo Ekonomiczne, Warszawa.

29. Redmond, W.H. (2005), "Processes of Gradual Institutional Drift", Journal of Economic Issues, Vol. 39 No. 2, pp. 501-509.

30. Ruef, M. and Scott, W.R. (1998), "A Multidimensional Model of Organizational Legitimacy: Hospital Survival in Changing Institutional Environments." Administrative Science Quarterly, Vol. 43, No. 4, pp. 877-904. https://doi.org/10.2307/2393619

31. Sagan A, Panteli D, Borkowski W, Dmowski M, Domański F, Czyżewski M, Goryński P, Karpacka D, Kiersztyn E, Kowalska I, Księżak M, Kuszewski K,Leśniewska A, Lipska I, Maciąg R, Madowicz J, Mądra A, Marek M, Mokrzycka A, Poznański D, Sobczak A, Sowada C, Świderek M, Terka A, Trzeciak P, Wiktorzak K, Włodarczyk C, Wojtyniak B, Wrześniewska-Wal I, Zelwiańska D, Busse R. (2011), Poland: Health system review. Health Systems in Transition, Vol. 13, No. 8, pp. 1-193.

32. Sekhri, N. and Savedoff, W. (2004), Private Health Insurance: Implications for Developing Countries, Geneva: World Health Organisations.

33. Smith, P.C. (2002), "Measuring health system performance", The European Journal of Health Economics, Vol. 3 No. 3, pp. 145-148. https://doi.org/10.1007/s10198-002-0138-1

34. Tobiasz-Adamczyk, B.; Brzyska, M.; Woz'niak, B. and Stanisław Kopacz, M. (2009), "The current state and challenges for the future of health promotion in Polish older people", International Journal of Public Health, Vol. 54, No. 5, pp. 341-348. https://doi.org/10.1007/s00038-009-0054-6

35. The World Bank (2014), Improving the financial sustainability of the hospital sector in Poland: towards a systemic approach: policy note, Washington DC: The World Bank.

International Journal of Management and Applied Research, 2017, Vol. 4, No. 3 
36. Zabdyr-Jamróz, M. (2015), "Health Systems in Transition (HiT) profile of Poland", The European Observatory on Health Systems and Policies, available at: http://www.hspm.org/countries/poland27012013/livinghit.aspx?Section=5.2\%20Pa tient $\% 20$ pathways \&Type $=$ Section\#19Patientsfacelongerwaitingtimesaftertheimple mentationofthe\%E2\%80\%9Cwaitinglistspackage\%E2\%80\%9Dandthe\%E2\%80\%9 Concologypackage \%E2\%80\%9D [accessed on 25 June 2017]. 